\title{
A NEW SPECIES OF THE GENUS MUNIDA LEACH, 1819 (DECAPODA, GALATHEIDAE) FROM MAURITIUS
}

BY

\author{
BELLA S. GALIL
}

National Institute of Oceanography, Israel Oceanographic and Limnological Research Ltd., P.O. Box 8030, Haifa 31080, Israel

\begin{abstract}
A new species of the genus Munida Leach, 1819 from the western Indian Ocean island of Mauritius is described and illustrated. The new species, M. barbeti, is closely related to M. gordoae Macpherson, 1994, M. leptosyne Macpherson, 1994, and M. evarne Macpherson \& De Saint Laurent, 1991.

\section{RÉSUMÉ}

Une nouvelle espèce du genre Munida Leach, 1819, de l'île Maurice, dans l'océan Indien occidental, est décrite et figurée. La nouvelle espèce, Munida barbeti, est étroitement apparentée à M. gordoae Macpherson, 1994, M. leptosyne Macpherson, 1994 et M. evarne Macpherson \& De Saint Laurent, 1991.
\end{abstract}

\section{INTRODUCTION}

Specimens of a galatheid crab recently obtained from Mauritius were identified as a new species belonging to the genus Munida Leach, 1819. The present note serves to describe and illustrate this new species, M. barbeti, and to discuss its affinities.

The specimens are deposited in the South African Museum (SAM), Cape Town.

\section{DESCRIPTION}

Munida barbeti sp. nov. (fig. 1)

Material examined. - Mauritius, Flic en Flac, 55 m depth, 11 May 1997, coll. Daniel Pelicier: 1 female 8.9 mm (SAM A43262), holotype; 1 female $7.6 \mathrm{~mm}$ (SAM A43263), paratype. 

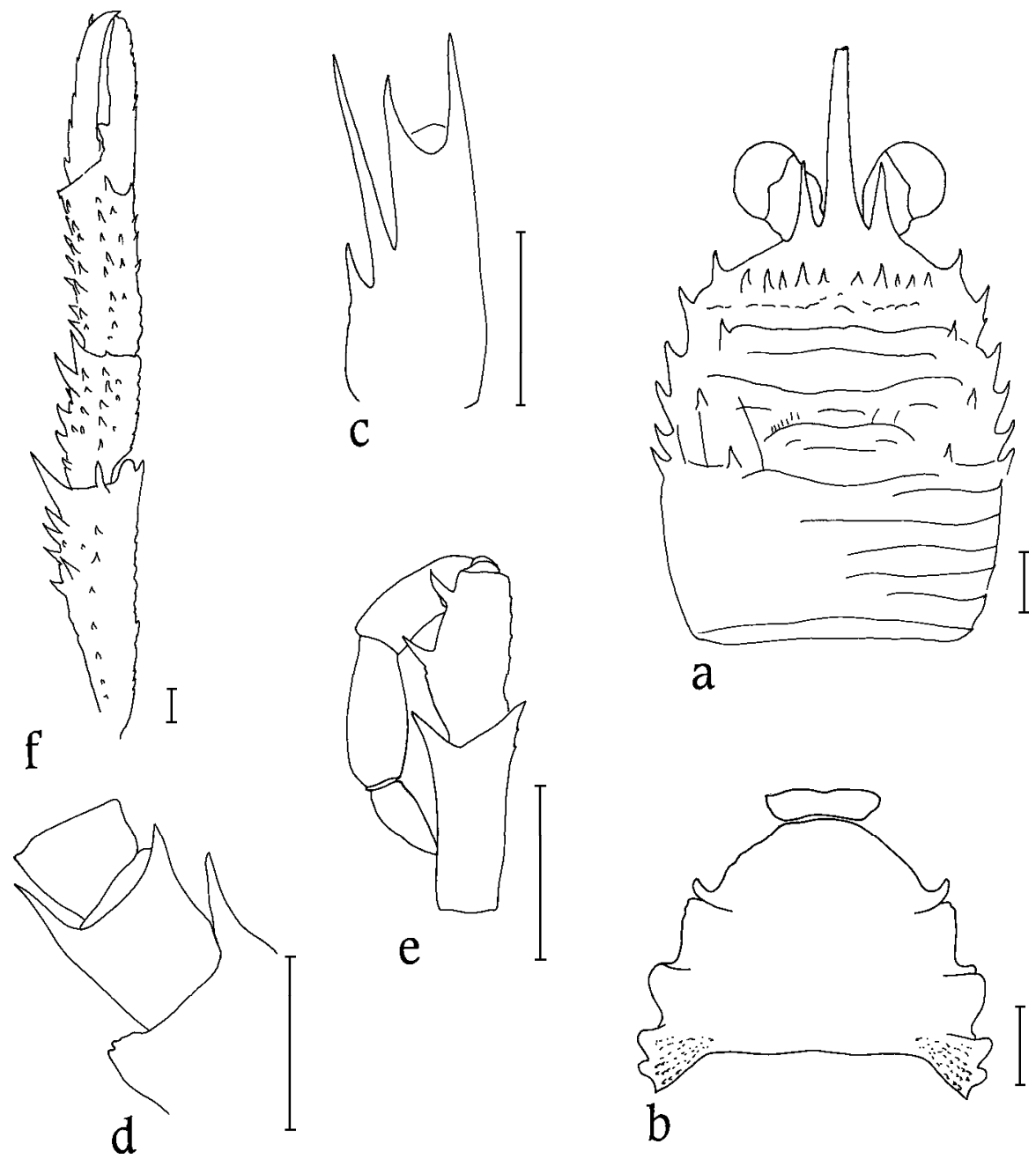

Fig. 1. Munida barbeti sp. nov., female $8.9 \mathrm{~mm}$, holotype (SAM A43262). a, carapace, dorsal view; $\mathrm{b}$, sternal plastron; c, antennular peduncle; d, antennal peduncle; e, third maxilliped; $\mathrm{f}$, cheliped.

Scales: $1 \mathrm{~mm}$.

Description. - Carapace longer than wide. Transverse ridges minutely granulate, densely set with short setae. Pair of long setae posteriorly to median pair of epigastric spines; 3 pairs of long setae laterally on posterior margin of cervical groove; one pair medially on anterior cardiac region. Four pairs of epigastric spines, largest pair just behind supraocular spines. Parahepatic spine followed by epibranchial spine. Spine on posterior margin of cervical groove in line with anterolateral, parahepatic spines.

Frontal margin strongly oblique, minutely granulate. Lateral margins slightly convex. First anterolateral spine short, second spine somewhat stouter, situated 
at anterolateral angle of carapace. Branchial margins with 4 spines, last one slimmer, undersized.

Rostrum straight, horizontal, less than half as long as carapace, minutely serrate anteriorly. Supraocular spines subparallel, upwardly directed, less than half as long as rostrum.

Fourth thoracic sternite with pair of setose arcuate striae anteriorly; fifth to seventh sternites smooth; transverse striae between fifth, sixth, and seventh sternites setose, minutely granulose. Seventh sternite with irregular rows of coarse granules laterally.

Second abdominal tergite with a row of 4 pairs of spines on anterior ridge. Second to fifth abdominal tergites each with one traverse setose stria.

Basal segment of antennule elongate, reaching well beyond eyes; two distal spines, mesial longer than lateral; two spines on lateral margin, proximal spine short, distal spine longer than distolateral, nearly as long as distomesial spine.

First segment of antennal peduncle with distomesial spine nearly reaching end of second segment. Second antennal segment with two distal spines, lateral spine longer than mesial spine. Penultimate segment unarmed.

Maximum corneal diameter equal to distance between tips of supraocular spines, one fourth of anterior border of carapace between bases of external orbital spines.

Ischium of third maxilliped 1.5 times as long as merus, bearing distoventral spine. Exterior margin of merus unarmed, interior margin bearing two subequal, slightly curved spines.

Chelipeds elongate, subequal, prominently spinose, setose. Merus slightly shorter than carapace, twice as long as carpus, dorsally spinose, spines increasing in size distally. Carpus with irregular rows of spines, larger distally. Chela with several rows of spines on upper, outer margins, one row continuing along fixed finger. Fingers crossing distally, cutting edges serrulate. Dactylus spinulose on upper margin. Pereiopods slender, setose. Meral dorsal margin bearing long plumose setae, spinose, spines increasing in size distally; large distoventral spine. Carpal dorsal margin spinose, large spines distally on dorsal and ventral margins. Propodus with row of 10 movable spines along ventral margin, increasing in size distally. Dactylus two-thirds as long as propodus, with 7 movable spinules along ventral margin, dactylar tip cornute.

Colour. - Carapace vivid red, triangular yellow patches on hepatic region. Abdomen red with round yellow patch anteriorly. Chelipeds and pereiopods striped red and yellow. 
Etymology. - This species is dedicated, by request of Daniel Pelicier, to Michel Barbet, his long-time diving partner. The epithet thus is a noun in the genitive singular.

Remarks. - M. barbeti is closely related to M. leptosyne Macpherson, 1994 and to M. gordoae Macpherson, 1994, both from New Caledonia and adjacent waters (cf. Macpherson, 1994), and to M. evarne Macpherson \& De Saint Laurent, 1991 from the Tubuai Islands, which all have quadrispinose branchial margins, and the lateral parts of the seventh thoracic sternite granulate (cf. Macpherson \& De Saint Laurent, 1991).

$M$. barbeti is distinguished from $M$. leptosyne by its more heavily spinose chela, a shorter dactylus, longer supraocular spines, and subequal spines on the internal margin of the third-maxillipedal merus. $M$. barbeti differs from $M$. gordoae in possessing epibranchial spines, a longer distal spine on the lateral margin of the basal antennular segment, and the slender, more heavily spinose chela. M. barbeti differs from M. evarne in possessing parahepatic, epibranchial, and postcervical spines, four pairs of spines on the second abdominal tergite rather than a single pair, and more prominent spines on the internal margin of the third-maxillipedal merus.

\section{ACKNOWLEDGEMENTS}

I am indebted to Dr. M. Smale for making the specimens available to me and to Dr. E. Macpherson for his comments on the manuscript.

\section{REFERENCES}

MacPherson, E., 1994. Crustacea Decapoda: studies on the genus Munida Leach, 1820 (Galatheidae) in New Caledonia and adjacent waters with descriptions of 56 new species. In: A. CROSNIER (ed.), Resultats des Campagnes MUSORSTOM, 12. Mém. Mus. natl. Hist. nat., Paris, 161: 421-569.

Macpherson, E. \& M. DE SAint Laurent, 1991. Galatheid crustaceans of the genus Munida Leach, 1818, from French Polynesia. Bull. Mus. natl. Hist. nat., Paris, 13 (A) (3/4): 373-422. 